\title{
PRODUKSI ENZIM LIPASE DARI Aspergillus niger ISOLAT KAPANG KOPRA DENGAN MENGGUNAKAN MEDIUM KELAPA PARUT
}

\author{
[Lipase Production from Aspergillus niger of Copra Mold Isolates Using Grated \\ Coconut Medium] \\ Indah $^{1^{\star}}$, Mappiratu $^{1}$, Musafira $^{2}$ \\ 1) Jurusan Kimia, Fakultas MIPA, Universitas Tadulako \\ J. Soekarno Hatta Km.9, Kampus Bumi Tadulako Tondo Palu, Telp. 0451- 422611 \\ 2) Universitas Sulawesi Barat \\ JIn. Prof. Dr. Baharuddin Lopa, SH, Talumung, Majene, Sulawesi Barat, Telp/Fax: (0422) 22559
}

*)Coresponding author: indaherlan09@gmail.com (hp: 082293580306)

Diterima 20 Juli 2017, Disetujui 10 Oktober 2017

\begin{abstract}
The investigation about the lipase enzyme production from Aspergillus niger using grated coconut as a medium has been done. The aim of the study is to determine the best incubation time, $\mathrm{pH}$ and water content which produced lipase enzyme with high activity. Randomized Block Design (RBD) with 2 factorial pattern (incubation time and $\mathrm{pH}$ of the medium) was used in this research. Each factor consists of three levels and it was done in triplo. The level of incubation time and of $\mathrm{pH}$ were 48,60, 72 hours and $\mathrm{pH} \mathrm{5,6}$, and 7, respectively. The observed parameter was the obtained lipase enzyme activity. The result showed that the highest activity was achieved at $\mathrm{pH} 7$ for 48 hours of incubation time with $45 \%$ of water content. The amount of lipase enzyme activity was $1.70 \mu \mathrm{mol} / \mathrm{ml}$.minutes.
\end{abstract}

Keywords: mold coconut, Aspergillus niger, lipase

\begin{abstract}
ABSTRAK
Telah dilakukan penelitian tentang produksi enzim lipase dari Aspergillus niger isolat kapang kopra dengan menggunakan medium kelapa parut. Penelitian ini bertujuan untuk menentukan waktu inkubasi terbaik, $\mathrm{pH}$ medium terbaik dan kadar air medium terbaik yang menghasilkan enzim lipase dengan aktivitas tertinggi. Penelitian dirancang menggunakan Rancangan Acak Kelompok (RAK) pola faktorial yang terdiri atas 1 faktor kelompok yaitu waktu inkubasi terdiri atas 3 taraf (48 jam, 60 jam dan 72 jam) dan 2 faktor yaitu $\mathrm{pH}$ medium terdiri atas 3 taraf $(\mathrm{pH} \mathrm{5,} \mathrm{pH} 6$ dan $\mathrm{pH}$ 7) dan kadar air medium terdiri atas 3 taraf yaitu $(25 \%, 35 \%$ dan $45 \%)$ yang masing-masing dilakukan secara triplo. Parameter yang diamati adalah aktivitas enzim lipase yang dihasilkan. Hasil penelitian menunjukkan waktu inkubasi terbaik adalah 48 jam, $\mathrm{pH}$ medium terbaik adalah $\mathrm{pH} 7$ dan kadar air medium terbaik adalah kadar $45 \%$ dalam produksi enzim lipase dengan aktivitas tertinggi yang diperoleh adalah 1,70 $\mu \mathrm{mol} / \mathrm{ml}$.menit.
\end{abstract}

Kata Kunci : Kelapa berjamur, Aspergillus niger, lipase 


\section{LATAR BELAKANG}

Pemanfaatan enzim dalam bidang bioteknologi dan industri semakin meningkat, oleh karena itu pengkajian enzim perlu dilakukan untuk dapat digunakan dalam bidang tersebut. Sifat enzim yang sangat spesifik dibandingkan dengan katalis anorganik menyebabkan enzim banyak digunakan dalam berbagai proses industri pangan maupun non pangan. Selain itu, lebih dari $70 \%$ industri kimia menggunakan enzim sebagai katalis. Hal tersebut dikarenakan penggunaan enzim mempunyai beberapa keuntungan, yaitu mempunyai aktivitas yang selektif, aman, mudah dikontrol, dapat didegradasi secara biologis, memiliki daya katalitik yang tinggi. Selain itu, reaksi enzimatik yang terjadi tidak menghasilkan produk samping dan enzim dapat aktif pada suhu dan $\mathrm{pH}$ tertentu, sehingga enzim sangat potensial untuk menggantikan katalis kimiawi dalam bidang industri (Lin et al.,1998).

Enzim yang cukup banyak dikaji adalah enzim lipase. Enzim ini dibutuhkan oleh beberapa industri, karena dapat menghasilkan asam lemak yang digunakan sebagai bahan baku pembuatan deterjen, pembuatan polimer dan zat pengemulsi pada industri farmasi. Gliserol selain digunakan untuk bahan peledak, banyak juga digunakan dalam bidang kosmetik dan obat-obatan (Crueger \& Crueger, 1984). Indonesia yang kaya akan keanekaragaman hayati memiliki peluan besar untuk mengembangkan produksi enzim lipase dari mikroba lokal. Adapun produksi lipase dapat dilakukan melalui teknik fermentasi secara substrat padat dengan menggunakan mikroorganisme khususnya kapang. Kapang merupakan jenis mikroba yang memenuhi $80 \%$ kebutuhan substratnya dari makromolekul berantai karbon (Putranto et al., 2006). Pemanfaatan kapang pada proses fermentasi memungkinkan terjadinya perombakan komponen bahan yang sulit dicerna menjadi lebih tersedia, sehingga dimungkinkan nilai nutrisinya juga meningkat. Kualitas produk fermentasi tergantung pada jenis mikroba serta medium padat yang digunakan. Kadar protein produk fermentasi menggunakan Aspergillus niger lebih baik dibandingkan dengan Rhizopus oligosporus (Kompiang et al., 1994).

Medium padat yang dapat digunakan pada penumbuhan Aspergillus niger ialah kelapa. Kelapa yang diolah menjadi kopra dimanfaatkan sebagai bahan baku pada industri pembuatan minyak nabati. Pembuatan kopra dapat dilakukan secara tradisional dalam beberap tahapan, meliputi pengupasan tempurung kelapa, penjemuran sampai kering, dan pengasapan. Pada proses pengolahan tersebut, seringkali dijumpai kopra yang rusak atau berjamur. Sekitar 1-5\% kelapa yang diolah menjadi kopra dapat berjamur, sehingga biasanya hanya menjadi limbah. Kopra yang berjamur tersebut dapat digunakan sebagai sumber mikroba 
penghasil enzim, seperti lipase. Kadar air yang masih tinggi pada kopra merupakan media yang baik untuk pertumbuhan mikroba utamanya jenis kapang. Jenis kapang yang biasanya tumbuh pada kopra dan telah teridentifikasi adalah Aspergillus niger dan genus Penicillium (Dali \& Pirman 2005).

Penggunaan Aspegillus niger sebagai sumber lipase ekstraseluler sangat potensial karena memiliki keunggulan dalam menghasilkan enzim ekstraselular dengan aktivitas tinggi dan pemeliharaannya yang mudah. Selain itu, secara ekonomi mudah didapat dengan harga yang murah dan berkembang pada media yang relatif lebih murah.

Murni et al. (2011) telah melakukan peneltian tentang produksi, karakterisasi, dan isolasi lipase dari Aspergillus niger dengan menggunakan induser minyak goreng sawit dan melaporkan bahwa aktivitas enzim lipase tertinggi (1,5 $\mu \mathrm{mol} / \mathrm{ml}$.menit) dicapai pada waktu 12 jam, $\mathrm{pH} 7$, dan suhu $30^{\circ} \mathrm{C}$.

Mengacu dari penelitian sebelumnya dan melihat banyaknya manfaat dari enzim lipase maupun Aspergillus niger, maka dalam penelitian ini akan dilakukan produksi enzim lipase dari Aspergillus niger isolat kapang kopra dengan menggunakan medium kelapa parut.

\section{METODE PENELITIAN}

\section{Bahan dan Peralatan}

Bahan utama yang digunakan dalam penelitian ini adalah kopra berjamur, daging buah kelapa parut kering, bahan lain terdiri atas bahan medium pertumbuhan mikroba untuk isolasi dan bahan kimia untuk analisis aktivitas enzim yang terdiri atas: medium Potato Dextrosa Agar (PDA), medium Nutrien Agar (NA), kalsium klorida, asam tartrat, alkohol, aseton, minyak zaitun, natrium klorida, indikator metil merah, indikator Phenopthalien, buffer posfat $(\mathrm{pH} \mathrm{5,6}$ dan 7), inokulum kapang Aspergillus niger, minyak kelapa, aseton-etanol (1:1 v/v) dan natrium hidroksida.

Peralatan yang digunakan dalam penelitian mencakup: labu ukur, corong bukhner, penangas air, buret, statif, klem, pipet, mesin kocok, neraca analitik, lemari pendingin, mikroskop, sterilisator, inkubator dan alat-alat gelas lain yang umum digunakan dalam Laboratorium Mikrobiologi Dan Laboratorium Kimia.

\section{Prosedur Penelitian}

Isolasi mikroba penghasil enzim lipase pada kopra berjamur (Mappiratu, 1997).

Kopra yang digunakan sebagai sampel adalah kopra berjamur. Isolasi kapang dilakukan menggunakan metode tuang. Kopra berjamur dihancurkan, kemudian ditimbang sebanyak 1 gram, selanjutnya disuspensikan dengan air destilata steril sebanyak $10 \mathrm{ml}$. Suspensi yang telah diperoleh diencerkan dengan pengenceran sampai $10^{-4}$. Larutan hasil pengenceran masing-masing diambil 0,1 $\mathrm{ml}$, kemudian dituangkan dalam agar cawan PDA yang mengandung asam 
tartrat $10 \%$ dengan kandungan $3 \mathrm{~g} / 100 \mathrm{~g}$ PDA. Medium ini adalah medium selektif untuk kapang. Medium agar cawan PDA yang telah diinokulasi diinkubasi pada suhu $37^{\circ} \mathrm{C}$ selama 3 hari. Kapang yang tumbuh dipindah tumbuhkan pada medium NA yang mengandung minyak zaitun $1 \%$, indikator metil merah 9,93\%. Medium yang telah diinokulasi tersebut diinkubasi pada suhu $37^{\circ} \mathrm{C}$ selama 3 hari. Koloni yang tumbuh yang mempunyai areal merah mudah disekelilingnya, dipindahkan pada agar miring PDA, diinkubasi pada suhu $37^{\circ} \mathrm{C}$ selama 3 hari. Kultur yang diperoleh diidentifikasi dan digunakan sebagai kultur untuk produksi lipase.

Produksi enzim lipase (Mappiratu, 1997)

Produksi lipase dilakukan pada medium padat, yakni pada medium kelapa parut kering dengan cara sebagai berikut : $50 \mathrm{~g}$ kelapa parut kering dimasukkan dalam Erlenmeyer $500 \mathrm{ml}$ kemudian ditambahkan larutan buffer posfat dengan $\mathrm{pH}$ sesuai perlakuan $(\mathrm{pH} 5, \mathrm{pH} 6, \mathrm{pH} 7)$. Penambahan buffer dilakukan sesuai perlakuan (25\%, 35\% dan $45 \%)$ atas dasar berat kelapa parut kering. Campuran diaduk hingga homogen, kemudian ditambahkan inokulum kapang Aspergillus niger konsentrasi $1 \%$ atas dasar berat kelapa parut kering. Campuram diinkubasi dengan inkubator bergoyang pada suhu ruang dengan waktu inkubasi sesuai perlakuan (48, 60 dan 72 jam). Lipase yang ada dalam medium diekstrak menggunakan larutan kalsium klorida 0,01
$\mathrm{M}$ dengan rasio 2:1. Campuran dikocok selama 1 jam diatas mesin kocok, selanjutnya disaring filtratnya ditampung sebagai larutan enzim lipase dan diuji aktivitasnya.

\section{Penetuan aktivitas enzim (Linfield et al., 1984)}

Minyak kelapa sebanyak $2 \mathrm{~g}$, dimasukkan kedalam erlenmeyer bertutup $500 \mathrm{ml}$, kemudian ditambahkan $4 \mathrm{ml}$ larutan buffer $0,01 \mathrm{M}(\mathrm{pH} \mathrm{6,0),} 1 \mathrm{ml}$ larutan kalsium klorida $1 \mathrm{M}$ dan $1 \mathrm{ml}$ filtrate (larutan enzim). Campuran selanjutnya diinkubasi pada inkubator bergoyang agitasi 300 rpm pada suhu ruang selama 1 jam. Setelah waktu inkubasi tercapai segera substrat enzim diinaktifkan dengan penambahan campuran aseton-etanol (1:1 $\mathrm{v} / \mathrm{v}$ ) sebanyak $10 \mathrm{ml}$. Lalu campuran dibuat homogen dengan pengocokan, kemudian ditambahkan 3 tetes indikator $\mathrm{pp}$ dan dititrasi dengan larutan natrium hidroksida standar sampai campuran berwarna merah jambu. Untuk blanko dilakukan dengan cara yang sama akan tetapi setelah ditambahkan enzim langsung ditambahkan dengan campuran aseton-etanol 1:1 (v/v). Aktivitas lipase yang dinyatakan dalam satuan $\mu$ mol FFA perml enzim permenit dihitung menggunakan persamaan :

$$
\text { Aktivitas lipase }=\frac{(\mathrm{A}-\mathrm{B}) \times \mathrm{N} \mathrm{NaOH} \times 1000}{\mathrm{~V} \times \mathrm{t}}
$$

Keterangan :

$$
\begin{array}{ll}
\mathrm{A} & =\text { volume } \mathrm{NaOH} \text { sampel }(\mathrm{mL}) \\
\mathrm{B} & =\text { volume } \mathrm{NaOH} \text { blanko }(\mathrm{mL}) \\
\mathrm{N} \mathrm{NaOH} & =0,05 \mathrm{~N} \\
1000 & =\text { nilai konversi dari mmol ke } \mu \mathrm{mol} \\
\mathrm{V} & =\text { volume enzim }(\mathrm{mL}) \\
\mathrm{t} & =\text { waktu inkubasi }
\end{array}
$$


HASIL DAN PEMBAHASAN

\section{Isolat kapang kopra Aspergillus niger penghasil enzim lipase}

Isolasi kapang penghasil lipase yang tumbuh pada kopra dilakukan menggunakan medium Potato Dextrosa Agar (PDA) selektif kapang yang dilanjutkan dengan medium Nutrien Agar (NA) yang mengandung minyak dan indikator metil merah (medium Morinaga et all., 1986). Medium nutrien agar ini merupakan medium selektif kapang penghasil lipase. Kapang yang memproduksi lipase akan menghidrolisis minyak menghasilkan warna merah muda dengan indikator metil merah sehingga kapang penghasil lipase akan menampakkan areal merah muda disekeliling koloni karena adanya indikator metil merah.

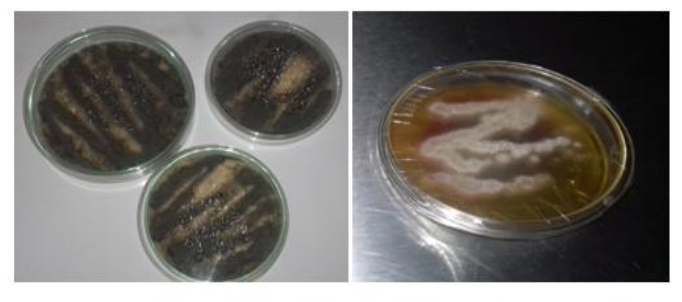

(Medium Potato Dextrosa Agar(PDA)) (Medium Nutrient Agar NA)

Gambar 1. Kapang Aspergillus niger dengan areal merah muda disekeliling koloni

Hasil pengamatan menunjukkan terdapat beberapa jenis kapang penghasil lipase yang tumbuh pada kopra. Hal ini ditandai dari adanya beberapa koloni yang menghasilkan areal merah muda disekeliling koloni. Kemudian dengan pemisahan lanjut untuk menghasilkan satu koloni ditemukan koloni yang berwarna hitam, hijau terang dan kuning kehijauan yang merupakan koloni penghasil lipase. Hal yang sama ditemukan oleh Mappiratu (1997), yang telah mengidentifikasi setiap koloni berdasarkan morfologisnya dengan menunjukkan bahwa morfologi koloni berwarna hitam merupakan morfologi kapang Aspergillus niger, koloni berwarna hijau terang sama dengan morfologi Aspergillus flavus dan koloni berwarna kuning kehijauan sama dengan morfologi kapang Rhizopus sp.

\section{Aktivitas Enzim Lipase Aspergillus niger Isolat Kapang Kopra.}

Produksi enzim lipase oleh kapang termasuk kapang Aspergillus niger dalam proses fermentasi dengan aktivitas enzim tertinggi dipengaruhi oleh beberapa faktor antara lain, faktor lama inkubasi, $\mathrm{pH}$ medium dan kadar air media (August, 2000). Hasil yang diperoleh memperlihatkan aktivitas enzim lipase yang terdapat pada Tabel 1.

Tabel 1 Aktivitas enzim lipase Aspergillus niger isolate kapang kopra

\begin{tabular}{|l|l|l|l|l|}
\hline Waktu & $\mathrm{pH}$ & \multicolumn{3}{|c|}{ Aktivitas enzim lipase pada kadar air (umolm.menit) } \\
\hline \multirow{4}{*}{48} & & $25 \%$ & $35 \%$ & $45 \%$ \\
\cline { 2 - 5 } & 5 & 0.92 & 1.06 & 1.28 \\
\cline { 2 - 5 } & 6 & 1.20 & 1.22 & 1.45 \\
\cline { 2 - 5 } & 7 & 1.33 & 1.53 & 1.70 \\
\hline \multirow{3}{*}{60} & 5 & 0.80 & 0.86 & 1.20 \\
\cline { 2 - 5 } & 6 & 0.97 & 1.17 & 1.28 \\
\cline { 2 - 5 } & 7 & 1.33 & 1.36 & 1.58 \\
\hline \multirow{3}{*}{72} & 5 & 0.14 & 0.17 & 0.64 \\
\cline { 2 - 5 } & 6 & 0.20 & 0.31 & 0.70 \\
\cline { 2 - 5 } & 7 & 0.47 & 0.53 & 0.78 \\
\hline
\end{tabular}




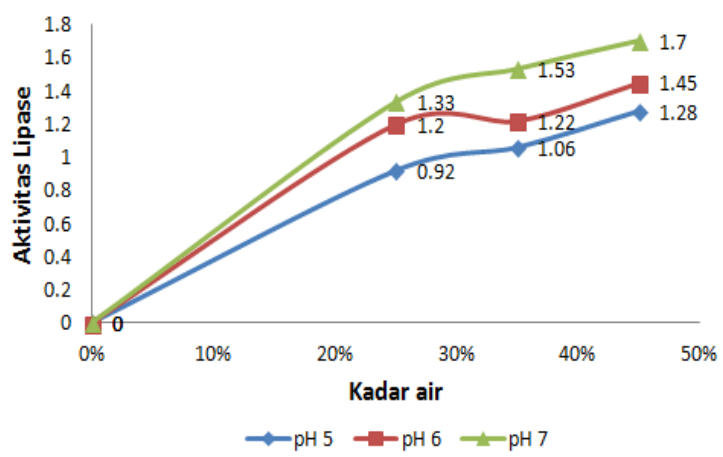

Gambar 2. Pengaruh pH medium dan kadar air medium terhadap aktivitas enzim lipase pada waktu 48 jam.

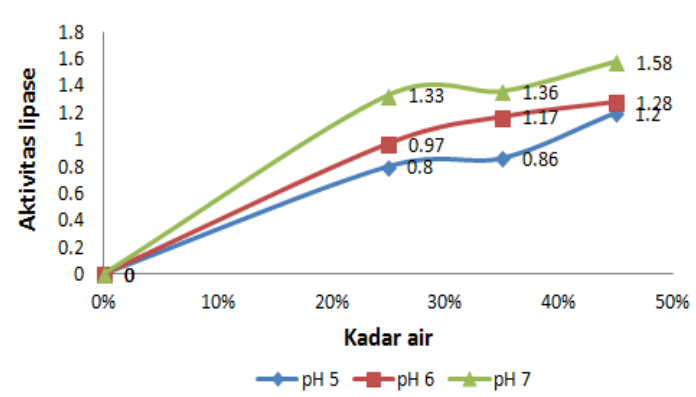

Gambar 3. Pengaruh pH medium dan kadar air medium terhadap aktivitas enzim lipase pada waktu 60 jam.

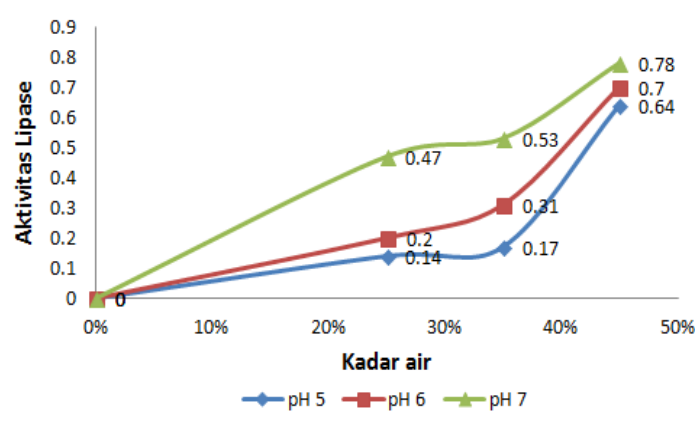

Gambar 4. Pengaruh pH medium dan kadar air medium terhadap aktivitas enzim lipase pada waktu 72 jam.

\section{Waktu inkubasi enzim lipase}

Berdasarkan ketiga gambar diatas (Gambar 2, 3 dan 4) menunjukkan bahwa aktivitas enzim lipase meningkat seiring dengan bertambahnya waktu fermentasi sampai pada hari ke dua, setelah itu terjadi penurunan aktivitas enzim lipase. Hal ini disebabkan karena pada hari pertama hingga hari ke dua (48 jam) pertumbuhan mikroba memasuki fase eksponensial. Namun setelah hari ke dua jumlah mikroorganisme menurun, berarti pertumbuhan telah memasuki fasa stationer dan fasa kematian karena nutrien di dalam medium dan energi cadangan di dalam sel sudah habis sehingga aktivitas enzim menurun dengan drastis.

Menurut Maryanty et al., (2010) dalam produksi crude lipase dari aspergillus niger pada substrat ongok menggunakan metode fermentasi fasa padat didapatkan hasil bahwa pada jam ke-36 sampai 60 jamur mengalami pertumbuhan terus menerus. Pada fase ini mikroba membelah dengan cepat dan konstan mengikuti kurva logaritmik. Pada waktu ke-72 sampai 108 merupakan fase stationer.

\section{pH maksimum enzim lipase}

Aktivitas enzim lipase dilakukan dengan variasi $\mathrm{pH}$ yaitu $\mathrm{pH} 5,6$ dan 7 . Hasil pengamatan aktivitas enzim lipase maksimum yang dicapai pada $\mathrm{pH} 7$ (netral). Menurut Christakopoulus (1992) dimana pada $\mathrm{pH}$ tinggi atau rendah memungkinkan terjadinya denaturasi dan ini akan mengakibatkan menurunnya aktivitas enzim. Karena enzim merupakan protein, perubahan $\mathrm{pH}$ akan menyebabkan ionisasi pada molekul protein berubah pula. Perubahan ini akan mengakibatkan struktur tiga dimensinya berubah sehingga 
fungsi katalitiknya terganggu. Hal tersebut dapat dilihat dari grafik diatas, pada aktivitas enzim pada $\mathrm{pH} 6$ masih menunjukkan aktivitas lebih rendah dibanding pada $\mathrm{pH}$ 7. Selain itu, terlihat pada ketiga gambar diatas, terdapat rentang $\mathrm{pH}$ yang dapat menyebabkan aktivitas lipase tertinggi, dan $\mathrm{pH}$ inilah yang dinamakan dengan $\mathrm{pH}$ optimum. Besarnya $\mathrm{pH}$ optimum yang sama, yaitu $\mathrm{pH}=7$ (netral), dilaporkan untuk lipase dari Calvatia gigantean (Christakopoulos, 1992). Selain itu, menurut penelitian Murni et al., (2011), dimana aktivitas enzim lipase optimum dari Apergilus niger berada pada $\mathrm{pH} 7$ dengan aktivitas sebesar 1,5 $\mu \mathrm{mol} / \mathrm{ml}$.menit.

\section{Kadar air enzim lipase}

Tingkat keasaman $(\mathrm{pH})$ larutan atau jumlah air pada medium sering diatur pada saat dilakukan inkubasi. Kadang-kadang jumlah air medium diatur saat dilakukan penambahan larutan asam maupun basa (bahan). Tingkat keasaman medium perlu diatur pada $\mathrm{pH}$ yang cocok untuk pertumbuhan mikroba karena kebanyakan mikroba hanya tumbuh pada daerah $\mathrm{pH}$ tertentu. Pengaturan tersebut biasanya dengan penambahan buffer yang cocok. Buffer adalah suatu larutan bahan kimia yang digunakan untuk mempertahankan $\mathrm{pH}$ suatu larutan. Salah satu buffer yang biasa dipakai adalah buffer fosfat. Pada penelitian ini digunakan buffer fosfat dengan berbagai kadar air yakni 25\%, $35 \%$, dan $45 \%$.
Berdasarkan hasil yang didapatkan kadar air 45\% merupakan aktivitas lipase tertinggi. Hal ini disebabkan karena kebanyakan jamur dapat tumbuh pada kisaran $\mathrm{pH}$ yang luas yaitu $\mathrm{pH}$ 2-8,5 tetapi biasanya pertumbuhannya akan lebih baik pada kondisi asam atau $\mathrm{pH}$ netral (Srikandi.F, 1989). Selain itu kadar air dari bahan juga sangat mempengaruhi laju reaksi enzimatik, kadar air yang rendah menghambat kerja enzim atau substrat, akibatnya hidrolisis hanya terjadi pada bagian substrat yang langsung berhubungan dengan enzim.

\section{KESIMPULAN}

Berdasarkan hasil penelitian yang telah dilakukan, didapatkan waktu inkubasi kapang Aspergillus niger pada medium kelapa parut yang menghasilkan enzim lipase dengan aktivitas tertinggi adalah pada waktu inkubasi 48 jam. $\mathrm{pH}$ medium yang menghasilkan enzim lipase dengan aktivitas tertinggi adalah $\mathrm{pH} 7$, sedangkan kadar air medium kelapa parut yang menghasilkan enzim lipase dengan aktivitas tertinggi adalah kadar air $45 \%$, dengan aktivitas tertinggi 1,70 $\mu \mathrm{mol} / \mathrm{ml}$.menit.

\section{UCAPAN TERIMAKASIH}

Secara khusus peneliti menyampaikan ucapan terima kasih kepada Laboran Jurusan Kimia dan Himpunan Mahasiswa Kimia (HIMAKIM) FMIPA UNTAD. 


\section{DAFTAR PUSTAKA}

August, E. G. 2000. Kajian lipase amobil dari Aspergillus niger pada pembuatan MAG yang bersifat antibakteri dati minyak kelapa. (Tesis). Bogor: Program Pasca Sarjana. Institut Pertanian Bogor.

Christakopoulos, P., Constantina Tzia, Dimitris Kekos, Basil J. Macris. 1992, Production and characterization of extracellular lipase from Calvatia gigantean. Journal Appl Microbiol Biotecnol. I32:194-197.

Crueger W., Crueger A. 1984. Biotechnology: A Textbook of Industrial Microbiology. Science Tech Inc. USA.

Dali S., Pirman. 2005. Eksplorasi dan Isolasi Enzim Lipase dari Fungi Inperfekti (genus Aspergillus dan Penicillium indigenus). Laporan Penelitian. Makassar: UNHAS.

Kompiang, I P., J. Darma, T. Purwadaria, A. Sinurat, Supriyati. 1994. Laporan Hasil Penelitian Protein Enrichment: Studi Cassava Enrichment melalui Proses Biologi bekerjasama dengan Proyek Pengembangan Penelitian Pertanian Nasional Badan Litbang Pertanian.

Lin, L. L., Chyau, C. C., Hsu, W. H. 1998. Production and Properties of a RawStarch Degrading Amylase from Thermophilic and Alkaliphilic Bacillus sp. TS-23. Biotechnology and Applied Biochemistry. 28 (4) : 61-68.

Linfield, W.M., D.J. O'Brien, S. Serota, R.A. Barauskas. 1984. Lipid- lipase interactions. I. Fat splitting with lipase from Candida rugosa. $J$. Am. Oil Chem Soc. 61 (1) : 10671071.

Mappiratu. 1997. Isolasi Mikroba Penghasil Enzim Protease, Amilase dan Lipase serta Pengujian Potensi Produksinya. (Tesis). Palu: Fakultas Pertanian Universitas Tadulako.

Maryanty Yanty, Hesti Pristianti, Paulina Ruliawati. 2010. Produksi Crude Lipase Dari Aspergillus niger Pada
Substrat Ongok Menggunakan Metode Fermentasi Fasa Padat. Jurnal Pengembangan Teknologi Kimia. 4 (2) : 59-64.

Morinaga, T, S. Kanda, R. Naomi. 1986. Lipase Production of a New Thermophilic Fungus Humicols lanuginosa Var. Catenulata. International Journal Ferment Technol. 64 (5) : 451-453.

Murni Sri Wahyu, Siti Diyar Kholisoh, Renaldo A. N., Nurul Arifin S. S. 2011. Produksi Enzim Lipase dari Aspergillus niger dengan Induser Minyak Goreng Sawit. Jurnal Pengembangan Teknologi Kimia. 21 (7) : 88-94.

Putranto, A.R., Santoso, D., TriPanji,Suharyanto, Budiani A. 2006. Karakterisasi Gen Penyandi Lipase dari Kapang Rhizopus oryzae dan Absidia corymbifera. Menara Perkebunan. 74(1):23-32.

Srikandi F.1989. Mikrobiologi Pangan. Bogor: Pusat antar Universitas Pangan dan Gizi. 